H. Vysoká, J. Bruthans, K. Žák, J. Mls - Response of the karst phreatic zone to flood events in a major river (Bohemian Karst, Czech Republic) and its implication for cave genesis. Journal of Cave and Karst Studies, v. 74, no. 1, p. 65-81. DOI: 10.4311/2010ES0178R

\title{
RESPONSE OF THE KARST PHREATIC ZONE TO FLOOD EVENTS IN A MAJOR RIVER (BOHEMIAN KARST, CZECH REPUBLIC) AND ITS IMPLICATION FOR CAVE GENESIS
}

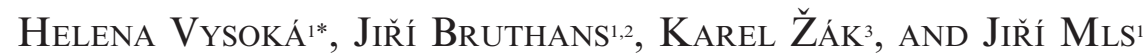

\begin{abstract}
Hydraulic and hydrochemical relationships between a medium gradient river and a karst aquifer were studied by water level and temperature logging combined with water geochemistry and $\delta^{13} \mathrm{C}$. The cave lakes are separated from the river by a floodplain up to $150 \mathrm{~m}$ wide formed by a gravel and sand layer up to $13 \mathrm{~m}$ thick covered with finegrained floodplain sediments. During minor discharge peaks (water level in the river $<1.5 \mathrm{~m}$ above the normal river stage), a water level oscillation in the cave lakes situated 40 to $190 \mathrm{~m}$ away from river is induced by the river level oscillation, but the river water does not enter any of the lakes. The groundwater chemistry in the cave lakes differs from that of the river water. Low bicarbonate content and high $\delta^{13} \mathrm{C}$ values indicate that some of cave lakes' waters have undergone $\mathrm{CO}_{2}$ degassing and calcite precipitation. During a major flood (recurrence interval $>100$ years, level rising $7 \mathrm{~m}$ above the normal stage), the river water rapidly flooded the caves through openings in the river canyon (floodflow injection), while those connected to the river via alluvium only were flooded by an elevated groundwater stage, and the resulting water level rise was only about 50 percent of the river level increase. A simple hydraulic model was successfully used to simulate and explain the water table oscillations in the cave lakes. Flood-flow injection has recently been substantially reduced by low-permeability, fine-grained late Holocene fluvial sediments that cap coarse gravels in the river floodplain. Fast speleogenesis by flood injection would be expected in periods when the river canyon was bare or filled by gravel alone (glacial periods, transition to Holocene). Ice jams causing local increases in the river level are recognized as one of factors that can be important in speleogenesis.
\end{abstract}

\section{INTRODUCTION}

Generally, direct invasion of river floodwaters into the karst environment enables fast development of caves (Palmer, 1991), since water in rivers originating outside of the karst area can be undersaturated with respect to calcium carbonate, and the mixing of river water and the usual karst $\mathrm{Ca}-\mathrm{HCO}_{3}^{-}$ waters is another factor enhancing corrosion of the limestone (Klimchouk et al., 2000). During the last few decades, injection of river floodwaters into karst porosity began to be considered as an important speleogenetic process (Palmer, 1991).

Choquette and Pray (1970) subdivided the evolution of carbonate rocks into three time or porosity stages reflecting the rock cycle. Deposition and early exposure are eogenetic; deep burial is mesogenetic; postburial exposure and erosion are telogenetic. Because karstification results from processes near the surface, karst can be subdivided into two main types, eogenetic and telogenetic (Vacher and Mylroie, 2002). Telogenetic aquifers differ from eogenetic aquifers not only in their much lower primary porosity and matrix permeability (Florea and Vacher, 2006), but also in the steeper inclination of their water table level (e.g., BaillyComte et al., 2010). Hydraulic and hydrochemical relationships between rivers and eogenetic karst aquifers were studied by Katz et al. (1998), Martin and Dean (2001), Opsahl et al. (2007) and others.
In telogenetic karst aquifers, the overwhelming majority of studies concerning the relationship between allogenic streams and karst aquifers are focused on partly or fully sinking streams (e.g. Bailly-Comte et al., 2009; Doctor et al., 2006). There is a lack of studies concerning the effect of a river that crosses the karst area but does not lose water into the karst aquifer under normal water stages.

The hydraulic and hydrochemical relationships between major low gradient or medium gradient rivers $(\leq 1 \mathrm{~m} / \mathrm{km}$ in this paper) crossing telogenetic karst areas and the phreatic zone in karstified limestone around the river represent a topic that is not yet fully understood. The valley bottoms of medium and low gradient rivers are typically filled with fluvial river sediments (Anderson and Anderson, 2010) and the sediment thickness is affected by climatic changes (e.g., Springer et al., 2009). Hydraulic conductivity and water exchange between the river and the karstic phreatic zone may be affected by the sedimentary valley fill.

\footnotetext{
* Corresponding Author

${ }^{1}$ Faculty of Science, Charles University in Prague, Albertov 6, 12843 Praha 2, Czech Republic. helenavysoka@hotmail.com

${ }^{2}$ Czech Geological Survey, Klárov 3, 11821 Praha 1, Czech Republic

${ }^{3}$ Institute of Geology, Academy of Sciences of the Czech Republic, v.v.i., Rozvojová 269, 16502 Praha 6 - Lysolaje, Czech Republic
} 
Where rivers freeze in the winter, the formation of either frazil-ice jams during river freezing or major ice jams during the spring snowmelt leads to the formation of river stretches with very steep gradients. Differences in the water level above and below the ice barrier can be as high as several meters (Matoušek, 2004). These events generate a steep hydraulic gradient between the river and the limestone aquifer.

The Bohemian Karst, located in the central part of the Czech Republic southwest of Prague, is a small karst area that is highly suitable for studying these relationships. The karst region is crosscut by a canyon of the Berounka River in a section about $8 \mathrm{~km}$ long. The Berounka River is a major, medium-gradient $(0.79 \mathrm{~m}$ per $\mathrm{km})$ river draining the western part of the Czech Republic. Altogether sixteen caves have been found around the river that either contain small permanent cave lakes or where water occurs periodically during river floods. This river valley suffered a major flood in August 2002 (a flood with recurrence interval of 500 to 1000 years; data from www.chmi.cz, MoE CR, 2003). Observations of the behavior of the cave lakes during this extreme event enabled us to formulate ideas about river-groundwater interaction during such major hydrological events. These observations prompted a more detailed study of the relationship between the river and the karst phreatic zone. The objective of this study is therefore to describe the hydraulic relationship between the Berounka River and nearby cave lakes during stable flow and flood events and also to describe the origin of the water in caves and its possible relationship to the river water. These data provide important information about the modern rate of speleogenetic processes.

\section{Regional Setting}

\section{The Bohemian Karst}

The Bohemian Karst is a small, isolated region with a total area of about $140 \mathrm{~km}^{2}$ consisting of Silurian to Middle Devonian limestones that were folded and faulted during the Hercynian Orogeny. These limestones are frequently folded deep below the surface and are interbedded with non-karstic rocks (Havlíček, 1989; Chlupáč et al., 2002). The limestones are either covered by Cretaceous platform sandstones and marls or are overlain by fluvial river terraces of Tertiary and Quaternary age (Včíslová, 1980; Kovanda and Herzogová, 1986; Kukla and Ložek, 1993). The area where caves and other karst features can be directly observed is therefore much smaller than the full $140 \mathrm{~km}^{2}$ area. While the northeastern part of the Bohemian Karst is flat, its southwestern part is hilly, with elevations between 208 and $499 \mathrm{~m}$ a.s.l. Deep valleys of local streams and especially of the Berounka River cut through this southwestern part. Relative elevation differences between the river valley bottom and its surrounding hills reach more than $200 \mathrm{~m}$. The present day climate of the area is moderate, with mean annual precipitation of $493 \mathrm{~mm}$ (measured at the
Beroun station, 1931-1960). The mean annual air temperature is between 8 and $9{ }^{\circ} \mathrm{C}$.

The known caves are developed mostly in the 120 to $300 \mathrm{~m}$ thick Lochkovian and especially the Pragian limestone, a high-grade limestone with usually more than 95 percent $\mathrm{CaCO}_{3}$ (Bruthans and Zeman, 2001, 2003). A total of 685 mostly small caves with a total length of $23.1 \mathrm{~km}$ have been mapped in the area as of December 31, 2010, according to the Cave Database of the Institute of Geology AS CR. Some 59 percent of them were found when exposed in limestone quarries. Three-dimensional phreatic mazes with multiple loops and irregular crosssections predominate in the Bohemian Karst. There are also several bathyphreatic caves (Bruthans and Zeman, 2003). The known depth of loops in the bathyphreatic caves exceeds $100 \mathrm{~m}$; continuations are either closed by cave sediments or too deep and narrow to be investigated by diving (Podtrat'ová Cave; Bruthans and Zeman, 2003).

The origin of the caves is not yet fully understood. Bosák et al. (1993) believed that the caves mostly originated by mixing-corrosion of river water with water from the limestone aquifer during the late Cretaceous and Paleogene, when the relief was relatively flat, with broad river valleys. Bruthans and Zeman (2001) proposed the idea of cave evolution by diffuse recharge from the Cretaceous sandstones that covered the whole region in the past and by injection of floodwaters of the Berounka River and its Tertiary precursor, the Paleo-Berounka River (Žák et al., 2001b). Some caves are clearly hydrothermal in origin (Cílek et al., 1994; Bosák, 1998); but there are no indications for hydrothermal origin in most of the caves in the area.

The main present-day regional aquifer is developed in the same lithological sequence as most of the caves (Bruthans and Zeman, 2001). Based on thermal modeling, recent groundwater circulation in the main aquifer occurs in synclines down to depths of about $600 \mathrm{~m}$ below the surface (Žák et al., 2001a). Sinks of surface streams, stream caves, dolines, and other surface karst features common in classical karst areas are generally absent in the Bohemian Karst (Bruthans and Zeman, 2003).

\section{The Berounka River And its Valley}

The study area (Fig. 1) surrounds an $8 \mathrm{~km}$ long section of the Berounka River canyon between the towns of Beroun and Karlštejn. The Berounka River is the only large stream in the area, with a catchment area of $8284.7 \mathrm{~km}^{2}$, mean flow rate of $35.6 \mathrm{~m}^{3} \mathrm{~s}^{-1}$, calculated 10-year flood flow $\left(\mathrm{Q}_{10}\right)$ of $799 \mathrm{~m}^{3} \mathrm{~s}^{-1}$, and calculated 100 -year flood flow $\left(\mathrm{Q}_{100}\right)$ of $1560 \mathrm{~m}^{3} \mathrm{~s}^{-1}$. During the August 2002 flood, the peak flow was $2170 \mathrm{~m}^{3} \mathrm{~s}^{-1}$. (All data are from the Beroun gauge, located just above the beginning of the karst canyon; data from www.chmi.cz, see also MoE CR, 2003). During normal summer water levels, the river elevation changes from 213 to $209 \mathrm{~m}$ a.s.l. The mean gradient of the water level of the Berounka River in the studied section is $0.64 \mathrm{~m}$ per $\mathrm{km}$, locally varying 


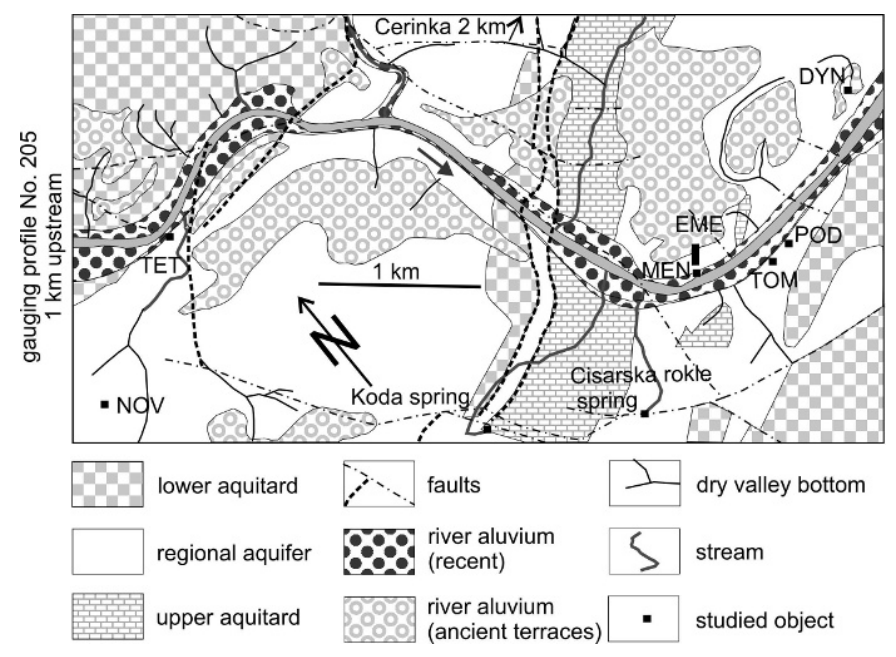

Figure 1. The study area along the Berounka River in the Bohemian Karst. The full names of the caves are given in the text. The geology is based on a 1:25,000 geological map (Havlíček, 1989).

between 0.4 and $1.1 \mathrm{~m}$ per km (Fig. 2). Overbank flooding begins approximately at a flow of $450 \mathrm{~m}^{3} \mathrm{~s}^{-1}$ (i.e., a waterlevel increase of more than $3 \mathrm{~m}$ ). Local streams entering the Berounka River in the Bohemian Karst have catchments up to tens of $\mathrm{km}^{2}$. Only the larger Kačák (Loděnice) stream has a larger catchment, $271.1 \mathrm{~km}^{2}$, and the mean flow at its confluence with the Berounka River is $0.53 \mathrm{~m}^{3} \mathrm{~s}^{-1}$. Most of the catchment area of the Kačák stream is outside of the karst area.

From written records and flood marks preserved in the river valley, it can be concluded that floods similar to the $\mathrm{Q}_{100}$ peak flow or higher occurred seven times during the last 500 years, in 1598, 1655, 1675, 1769, 1784, 1872, and 2002 (Elleder, 2004; Žák and Elleder, 2007). The highest flood ever recorded occurred on May 25, 1872, when the maximum water level in the village of Srbsko, in the middle of the studied river section, was $7.7 \mathrm{~m}$ above the usual level there, $0.47 \mathrm{~m}$ higher than during the 2002 flood (Žák and Elleder, 2007).

The August 2002 flood affected most of the Czech Republic. The Berounka River water level rose as a result of heavy rains that occurred August 6-13 in southwestern Bohemia. River peak at the Beroun gauge occurred at midnight on August 13, with peak flow of $2170 \mathrm{~m}^{3} \mathrm{~s}^{-1}$ (www.chmi.cz). The mean river slope during the flood was similar to that of the normal water stage, $0.66 \mathrm{~m}$ and $0.64 \mathrm{~m}$ per $\mathrm{km}$, respectively (data from Žák and Elleder, 2007; see Fig. 2). Local variations in the gradient were smaller during the flood compared to normal flow.

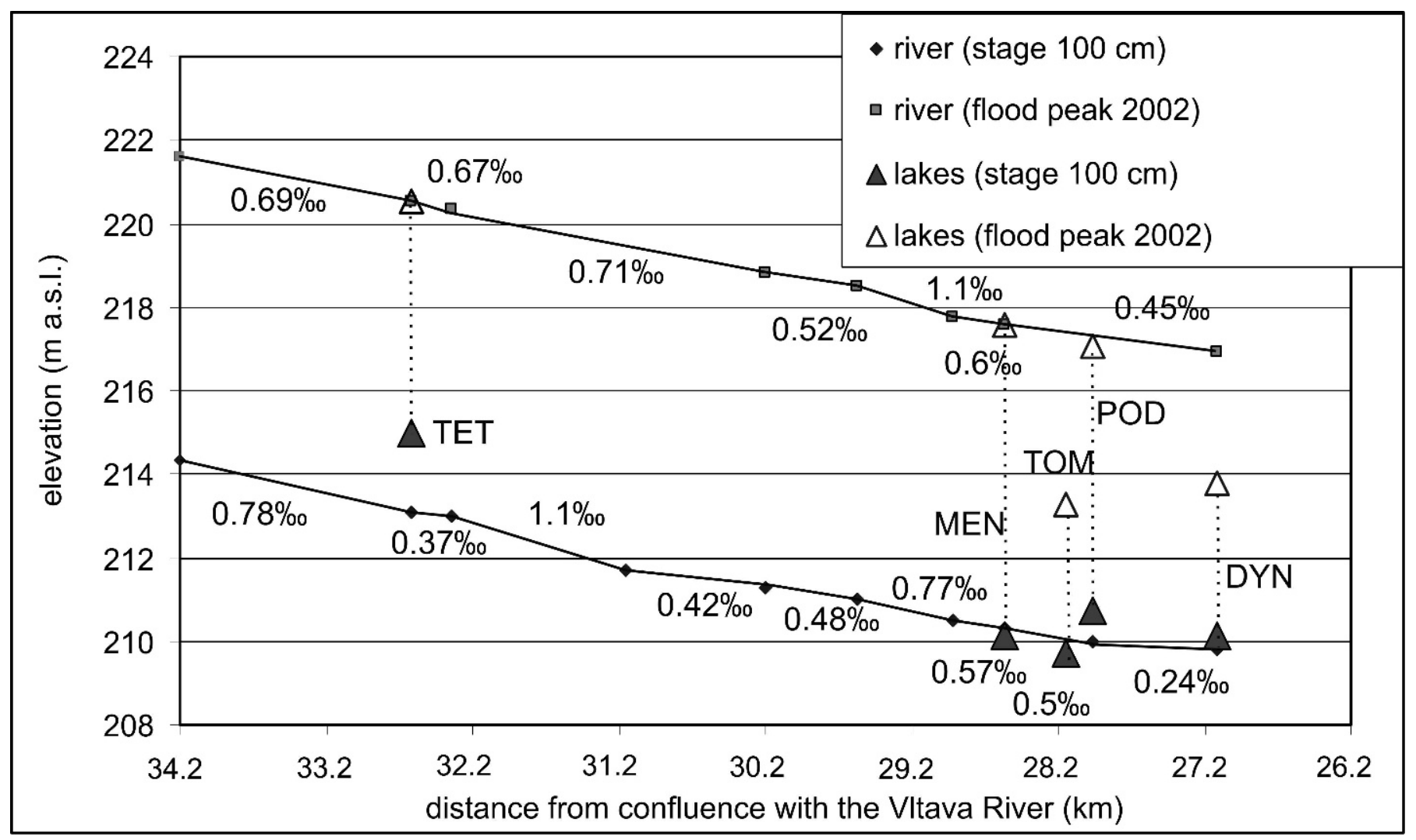

Figure 2. Profile of the Berounka River (Žák and Elleder, 2007). Triangles represent the elevations of the cave lakes. The lower line and solid triangles are for normal flow $(100 \mathrm{~cm}$ on the Beroun gauge), and the upper line and open triangles are for the peak of the 2002 flood. The gradients (\%o or $\mathbf{m}$ per $\mathbf{k m}$ ) are indicated for local stretches of the river. 
Table 1. Parameters of the cave lakes.

\begin{tabular}{|c|c|c|c|c|c|c|c|c|}
\hline Cave & Abbreviation & $\begin{array}{l}\text { Cave length } \\
\text { (m) }\end{array}$ & $\begin{array}{c}\text { Cave lake } \\
\text { above the } \\
\text { Berounka } \\
\text { river }(\mathrm{m})\end{array}$ & $\begin{array}{l}\text { Lake depth } \\
\text { (m) }\end{array}$ & $\begin{array}{l}\text { Lake surface } \\
\qquad\left(\mathrm{m}^{2}\right)\end{array}$ & $\begin{array}{l}\text { Distance } \\
\text { from river } \\
\quad(\mathrm{m})\end{array}$ & $\begin{array}{l}\text { Distance } \\
\text { from river } \\
(\mathrm{m})\end{array}$ & $\begin{array}{c}\text { Landuse } \\
\text { above cave }\end{array}$ \\
\hline Podtratova & POD & 180 & \pm 0.3 & 67 & 18 & 55 & 20 & $\begin{array}{l}\text { unused; } \\
\text { bushes }\end{array}$ \\
\hline Tomaskova & TOM & 80 & \pm 0.3 & 2 & 5 & 170 & 120 & $\begin{array}{l}\text { abandoned } \\
\text { quarry; } \\
\text { bushes }\end{array}$ \\
\hline Dynamitka & DYN & 180 & \pm 0.3 & 1.5 & 12 & 190 & 140 & $\begin{array}{l}\text { abandoned } \\
\text { quarry; } \\
\text { forest }\end{array}$ \\
\hline $\begin{array}{l}\text { Menglerova/ } \\
\text { Emental }\end{array}$ & MEN/EME & $15 / 1884$ & \pm 0.3 & 6 & $14 / 50$ & 40 & 0 & $\begin{array}{l}\text { unused; } \\
\text { bushes- } \\
\text { agricultural } \\
\text { land }\end{array}$ \\
\hline Tetinska & TET & 8.5 & +1.9 & 0,5 & $0-8$ & 50 & 0 & $\begin{array}{l}\text { unused; } \\
\text { bushes - } \\
\text { buildings }\end{array}$ \\
\hline Nova & $\mathrm{NOV}$ & 156 & +70 & $0-15$ & $0-75$ & 1200 & 1200 & $\begin{array}{l}\text { abandoned } \\
\text { quarry; } \\
\text { bushes }\end{array}$ \\
\hline
\end{tabular}

a Nominal stage.

${ }^{\mathrm{b}}$ Flood culmination 2002 .

The evolution of the studied section of the Berounka River valley during the Tertiary and Quaternary was quite complex. Starting in the Oligocene and early Miocene, the paleo-Berounka River formed a wide valley with bottom located about $70 \mathrm{~m}$ above the present riverbed (Kukla and Ložek, 1993; Žák et al., 2001b). The same wide valley was used again during the early Pleistocene. During the Pleistocene, after $780 \mathrm{ka} \mathrm{BP}$, as indicated by paleomagnetic and paleontological studies (Horáček and Ložek, 1988; Kočí, 1991; Kovanda, 1991), the Berounka River started to cut a narrow canyon, in which individual river terraces, corresponding to middle Pleistocene climatic changes, are preserved locally. The area of the Bohemian Karst was never glaciated during the Quaternary. During the last glacial period (Weichselian), the deepest level of the river bottom was several meters below the present bed. During the late Weichselian or early Holocene, the bottom of the valley was filled in with gravel and sand, forming a flat floodplain. These coarse-grained alluvial sediments are 8.0 to $13.5 \mathrm{~m}$ thick, based on borehole data (Včíslová, 1980), and are usually covered by a 0.5 to $2.5 \mathrm{~m}$ thick layer of late Holocene fine-grained fluvial sediments (Žák et al., 2010).

The hydraulic conductivity of the coarse alluvium ranges between $10^{-4}$ and $10^{-2} \mathrm{~m} \mathrm{~s}^{-1}$, based on pumping tests conducted over the area (Včíslová, 1980). The vertical hydraulic conductivity of the late Holocene fine-grained fluvial cover of the floodplain varies between $10^{-5}$ and $10^{-4} \mathrm{~m} \mathrm{~s}^{-1}$, based on field infiltration tests. The hydraulic conductivity of the limestone aquifer (mainly fracture and karstic porosity) is between $10^{-8}$ and $10^{-4} \mathrm{~m} \mathrm{~s}^{-1}$, based on pumping tests in the area (Včíslová, 1980). The storativity of the limestone aquifer, derived from integration of the spring yield together with monitoring of the water level recession at the boreholes, is 3 to $7 \%$ o (Bruthans and Zeman, 2000).

\section{Studied Caves}

Six caves that contain small lakes and are located on both sides of the river were chosen for regular monitoring (Table 1, Fig. 1). Five of them are situated relatively close to the Berounka River: Menglerova Cave (abbreviated MEN), which is connected with the Ementál Cave (EME) by an open conduit (sump), Dynamitka Cave (DYN), Podtraťová Cave (POD), Tomáškova Chasm (TOM), and Tetínský Vývěr Cave (TET). These caves occur between 40 and $190 \mathrm{~m}$ from the river channel. The Nová na Damilu Cave (NOV), situated approximately $1 \mathrm{~km}$ away from the river at a much higher elevation, with no river influence but with highly variable water level, was also included. Since the studied caves are located within the steep slopes of the canyon, the unsaturated zone above the cave lakes is several tens of meters thick. Under normal flow conditions, the river channel is not directly connected with any of studied cave lakes. The alluvial sediments block direct, rapid infiltration of river water into the limestone aquifer. Under the flood regime, the water level in the river reaches solutional openings in the limestone sides of the canyon 


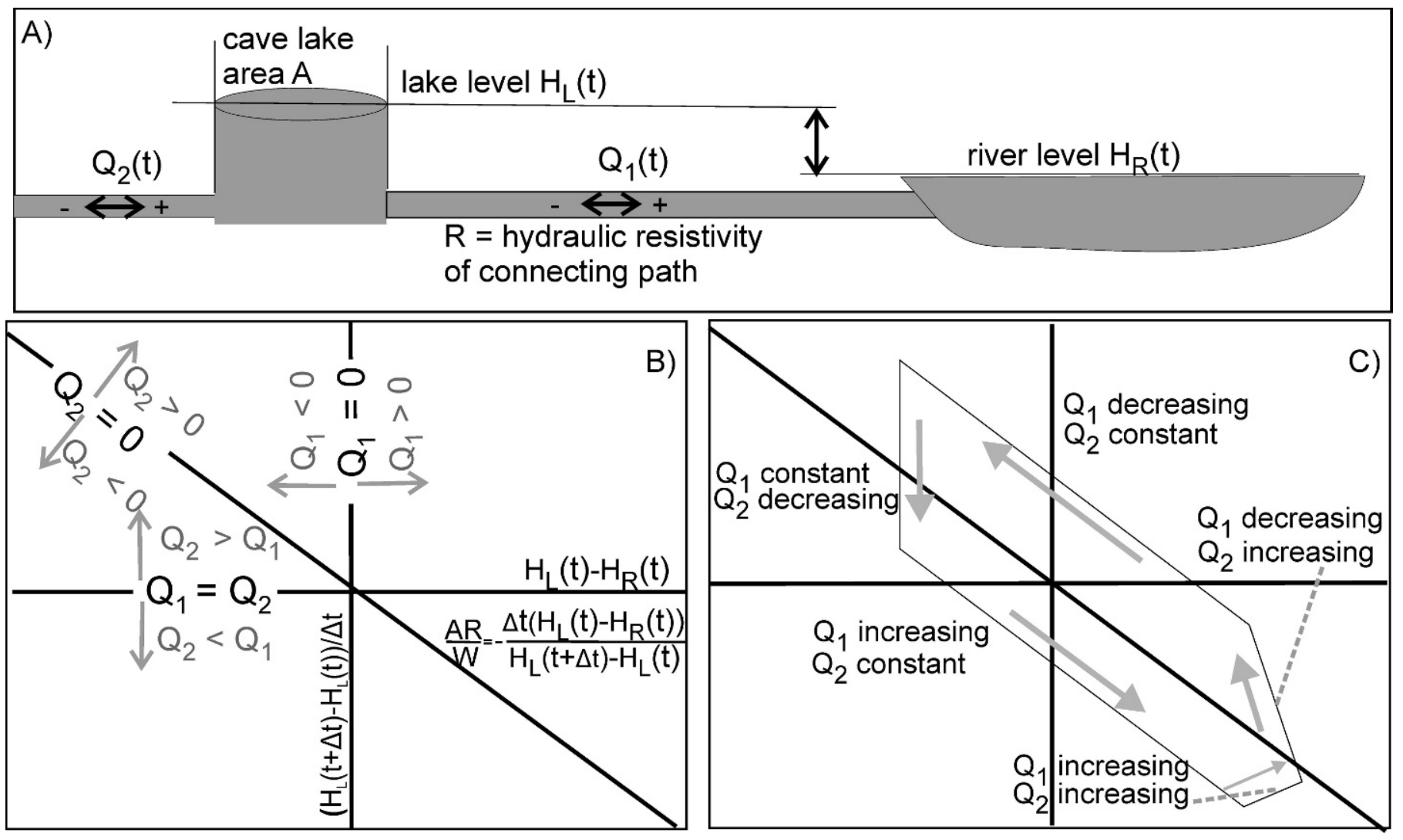

Figure 3. The model of the hydraulic relationship between the river and a cave lake. See Equations 3-6. A. The geometry of the model. B. Relationship of $Q_{1}$ and $Q_{2}$ to the axes in Figure 6. C. An example of a possible time evolution of $Q_{1}$ and $Q_{2}$.

(mostly the entrances of the caves). In the MEN-EME cave system, sedimentary evidence shows that floodwaters can rapidly reach even very distant parts of the cave, and is a perfect example of a flood-flow labyrinth (sensu Palmer, 1991).

Quarries close to the studied caves have quarry bottoms above the highest groundwater level and the highest floods. Quarry debris does not block the artificial entrances anywhere. Above the active phreatic and epiphreatic zones, the studied caves have dry, now inactive sections that extend up to several tens of meters above the groundwater level. These dry sections were locally partly quarried out, but did not impact on deeper cave sections. Therefore, the influence of quarrying on the hydraulic regime of studied caves can be considered to be negligible.

\section{Methods}

The maximum water level of the August 2002 flood in the valley and in the caves was marked for later measurements. After the flood, plastic water-gauging laths were placed and fixed by screws in the six caves, as well as on the bank of the Berounka River close to the caves. The altitudes and positions of the laths outside the caves and cave entrances were measured by a total station with precision of $\pm 5 \mathrm{~mm}$ (Sokkia and Topcon). The peak water levels of the 2002 flood at several profiles within the studied valley and the elevations of historical flood marks were measured in the same way. The data of Žák and Elleder (2007) were used for comparison. The elevations of the laths inside caves were measured by a precise inclinometer and a laser rangefinder (Disto Lite 5, Leica Co.).

Three cave lakes (in MEN, DYN, and POD Caves) were equipped with pressure and temperature sensors (Lucas) connected with data loggers and automatically measuring the water level and temperature every 30 minutes with an accuracy of $\pm 1 \mathrm{~cm}$ and $\pm 0.03{ }^{\circ} \mathrm{C}$, respectively (LGR, Geomon Co.). The submerged pressure sensors are connected to the atmosphere by a capillary tubes to compensate for air pressure changes.

The conductivity, temperature, and $\mathrm{pH}$ were measured in the cave lakes and river water using portable devices (Cond 340i, pH 330i, WTW Co.) on a monthly basis. The cave lakes and the Berounka River were sampled monthly for chloride, a conservative tracer. Samples for major chemical analysis were taken during high flow (April 2003) and low flow (September 2003). Samples for ${ }^{13} \mathrm{C}$ and major chemistry were taken in October 2007.

Water chemistry was analyzed by FAAS, HPLC, and titration in the laboratories of the Czech Geological Survey. Samples for chloride content were analyzed by argentometric titration. Samples for the ${ }^{13} \mathrm{C}$ determination 
of $\mathrm{HCO}_{3}^{-}$were collected in vapor-tight containers with zero headspace, and the bicarbonate was immediately precipitated as $\mathrm{BaCO}_{3}$ in the laboratory. For the isotope measurement, the $\mathrm{BaCO}_{3}$ was converted to $\mathrm{CO}_{2}$ by the usual reaction with $100 \% \mathrm{H}_{3} \mathrm{PO}_{4}$. The ${ }^{13} \mathrm{C}$ measurements were performed on a Finnigan Mat 251 Mass Spectrometer in the laboratories of the Czech Geological Survey with an analytical error of $\pm 0.1 \%$. The results are expressed in the usual delta notation against the international PDB standard.

The saturation indexes with respect to calcite were calculated from the chemical analyses data and field $\mathrm{pH}$ measurements using the PHREEQC 2.14 code (Parkhust and Appelo, 1999).

Communication between the river and the limestone caves through the alluvium was modeled as nonstationary 1D flow in a vertical plane normal to the river flow and assumed an unconfined aquifer. The model was governed by the nonlinear parabolic partial differential equation

$$
S \frac{\partial u}{\partial t}=\frac{\partial}{\partial x}\left(K u \frac{\partial u}{\partial x}\right)
$$

where $x$ is the distance from the river, $t$ is time and $u$ is the hydraulic head. The model contains two parameters, hydraulic conductivity $K$ and the storativity $S$ of the aquifer. The Rothe method was applied to discretize the problem in time, and the Galerkin method with finite elements was utilized when solving the resulting elliptic boundary value problem. The output data are the hydraulic head $u$ and discharge $q$ given by

$$
q=-K u \frac{\partial u}{\partial x}
$$

The model and the measured data sets were used to solve the inverse problem of determining the model parameters at the three locations. The first results made it obvious that the connecting paths between the river and cave lakes are under confined aquifer conditions. This allowed the authors to introduce transmissivity $T$ and to simplify the model in the linear form

$$
S \frac{\partial u}{\partial t}=T \frac{\partial^{2} u}{\partial x^{2}}
$$

Equation (3) was used to simulate the hydraulic head propagation between the river and the cave lakes. The low values of the storativity made it possible to assume $S=0$ and to further simplify the model, illustrated in Figure 3, to

$$
\begin{gathered}
Q_{1}(t)=W \frac{H_{L}(t)-H_{R}(t)}{R}, \\
H_{L}(t)=H_{L}(t-\Delta t)+\Delta t \frac{Q_{2}(\mathrm{t}-\Delta t)-Q_{1}(\mathrm{t}-\Delta t)}{A},
\end{gathered}
$$

or more simply

70 • Journal of Cave and Karst Studies, April 2012

$$
Q_{2}(\mathrm{t})=A \frac{H_{L}(\mathrm{t}+\Delta t)-H_{L}(t)}{\Delta t}+Q_{1}(\mathrm{t})
$$

where

$$
R=\frac{L}{T}
$$

$H_{R}(\mathrm{t})$ is the river level, $H_{L}(\mathrm{t})$ is the lake level, $Q_{1}(\mathrm{t})$ is the flow between the cave lake and the river, $Q_{2}(\mathrm{t})$ is the flow between the cave lake and the limestone aquifer. $W$ is the width of the aquifer parallel to the river (m), $A$ is the area of the cave lake (including unknown cave lakes in the vicinity of the cave), $R$ is the hydraulic resistivity of the connecting path between the river and the cave lake, $T$ is the transmissivity of the flowpath $\left(\mathrm{m}^{2} \mathrm{~s}^{-1}\right)$, and $L$ is the distance between the cave lake and the river along the flowpath. $R$ and $A$ are considered to be constant in time, which may be a considerable simplification of reality (see below in the discussion of the simulation). $Q_{1}(\mathrm{t}), Q_{2}(\mathrm{t}), R$, and $A$ are unknown, but plotting the measured values of $H_{L}(\mathrm{t}+\Delta \mathrm{t})$ $-H_{L}(\mathrm{t}) / \Delta \mathrm{t}$ and $H_{L}(\mathrm{t})-H_{R}(\mathrm{t})$ for each cave lake in Figure 3 enables us to directly determine if $Q_{1}(\mathrm{t})$ and $Q_{2}(\mathrm{t})$ are positive or negative and which one is increasing or decreasing at a given time in the course of the flood.

\section{RESUlts AND Discussion}

\section{Relationship Between the Water Level in the River and in the Cave Lakes}

At steady state, the water levels in the cave lakes are at the same elevation as the water level at the closest point in the river within a measurement error of $\pm 0.3 \mathrm{~m}$. The only exceptions are the TET Cave, with an average water level of $+1.9 \mathrm{~m}$ above the river, and the NOV Cave, which is about $1 \mathrm{~km}$ away from the river.

A total of twelve water level peaks with amplitudes of up to $1.5 \mathrm{~m}$ were documented between January and July 2004 (Fig. 4). The water oscillations in all the caves were very similar (the Pearson correlation coefficient among the cave lakes was between 0.977 and 0.990 ). The river water did not directly enter the caves during the period of automatic logging. The river and the cave lakes were thus hydraulically connected only via the saturated zone of the Quaternary gravels in the river alluvium.

The Beroun gauging station used for monitoring the water level in the river is situated 5.5 to $7.0 \mathrm{~km}$ upstream from cave lakes POD, DYN and MEN included in Figure 4. Propagation of the flood peaks down the Berounka River occurred at average speeds of 3.5 to $7.0 \mathrm{~km} \mathrm{~h}^{-1}$, based on nine flow peaks in 2004. The delay between gauging station and the river in front of caves is thus in order of 1 to 2 hours, which can be neglected since individual peaks last tens of hours and more. There was a high correlation between the levels of the river and of the 


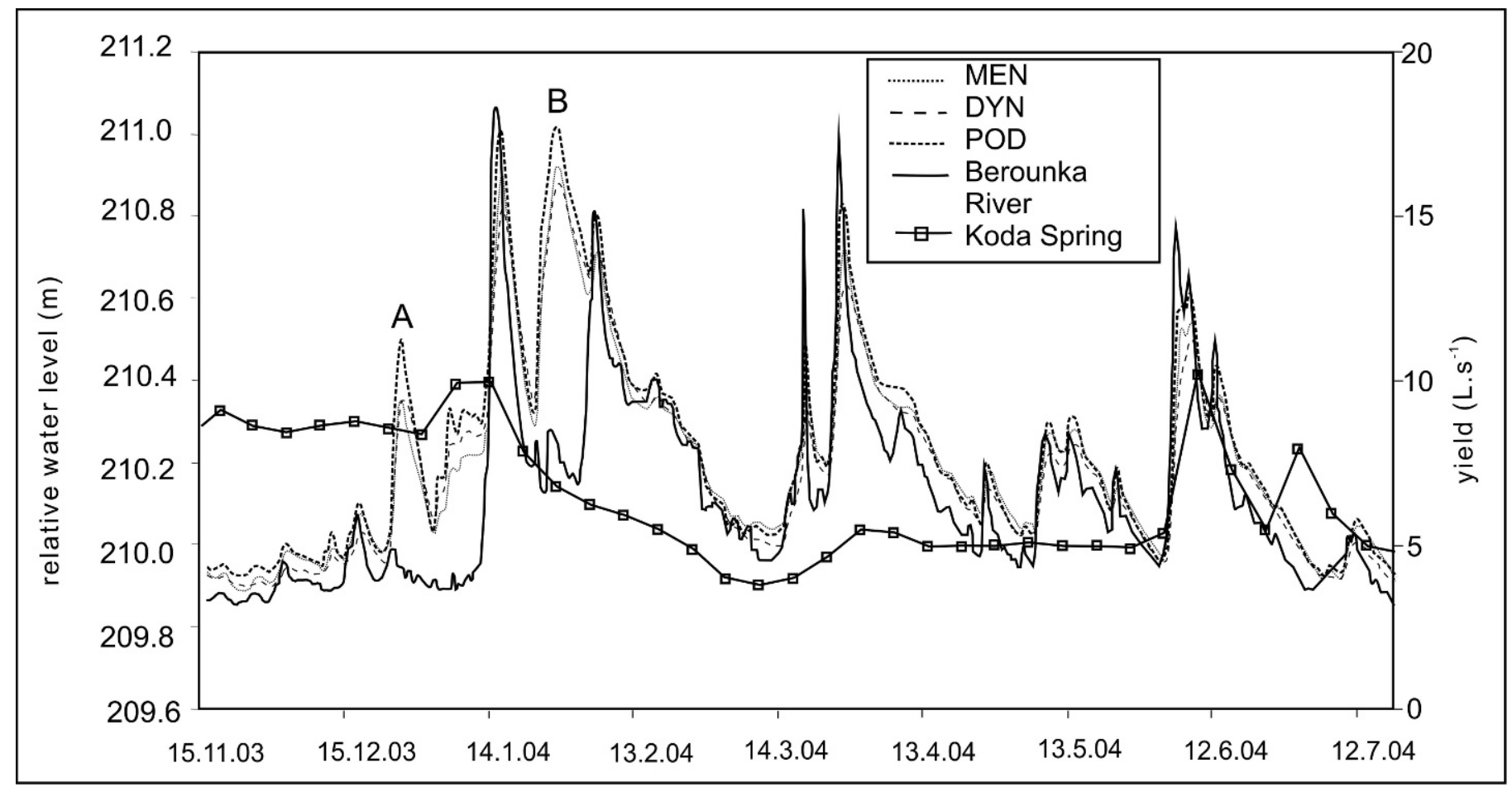

Figure 4. Water level in the river at the Beroun gauge and water levels in some cave lakes. The yield of the Koda Spring (Fig. 1; right axis) is shown for comparison. Note that the vertical position of a lake trace may be off by up to $0.3 \mathrm{~m}$. Peaks $\mathrm{A}$ and $B$ are due to winter ice jams downstream from the caves that affected the river near the caves but did not affect the river at the gauge. The time scale is day.month.year after 2000.

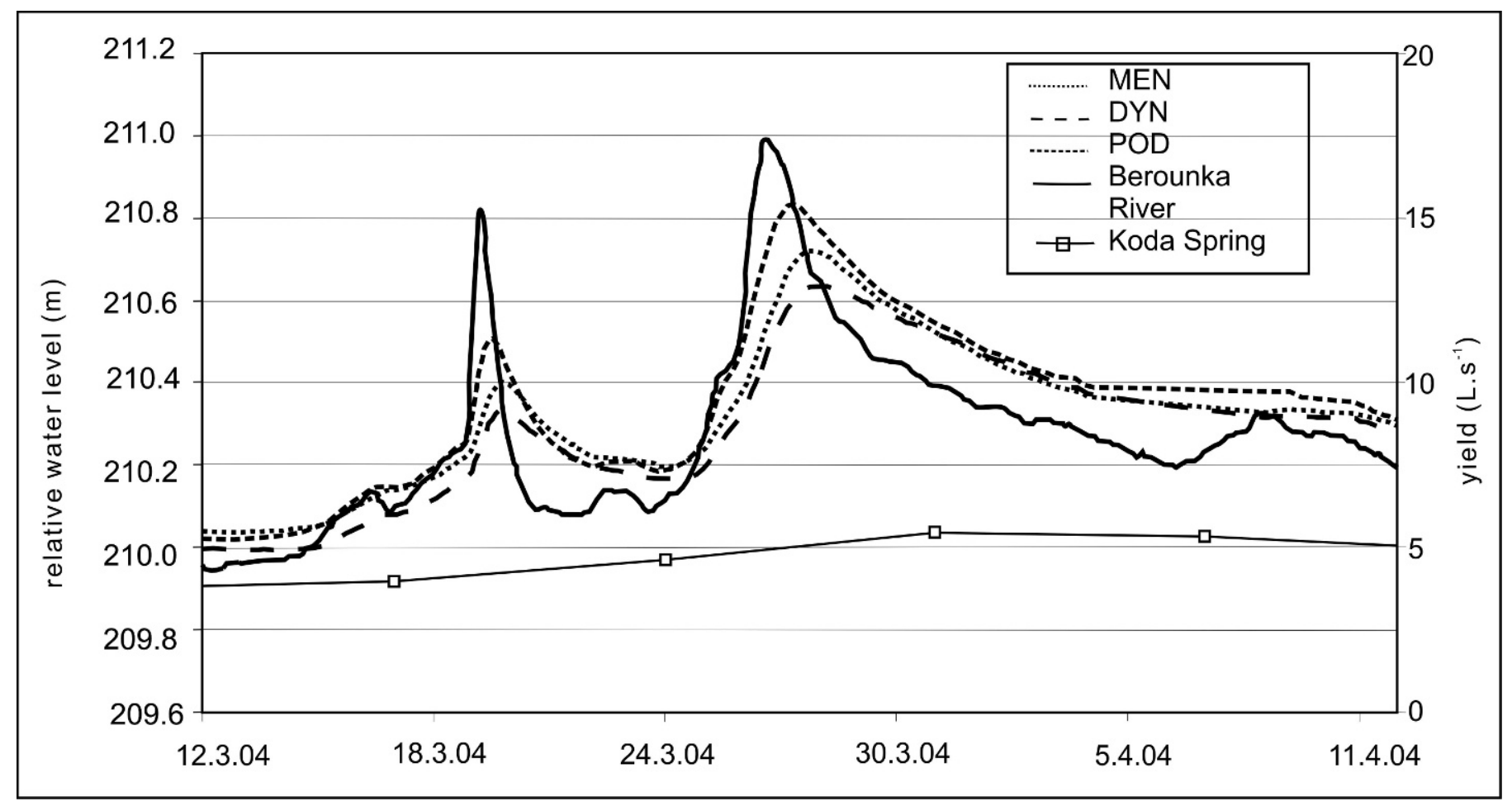

Figure 5. Detail from Figure 4 of March and early April 2004. See the caption for Figure 4 for explanation. 
cave lakes. Once the river level started to rise, the lake levels rose as well, but slightly more slowly. During all the events, the fastest reaction was observed in the POD Cave, and the slowest and least prominent increase was in the DYN Cave (Fig. 5). This probably reflects the longer distance between the river and the DYN Cave (Table 1). The cave lake levels were mostly still rising when the river level started to fall. Lake levels started to decline when the river level became lower than the lake levels (Fig. 5). The lake levels' decline was very slow, taking several weeks to several months to return to the river level. Short periods with the river level above that of the cave lakes, compared to relatively long periods of the opposite relationship show that river water tends to flow into the limestone aquifer only during flood peaks. During most of time, water drains from the limestone aquifer into the river.

During the winter, two water level peaks were observed in the cave lakes that were not connected to peaks in the river level (periods designated A and B in Fig. 4). Nothing similar to these peaks was observed in the water levels of local wells or springs or in stream discharges. These oscillations of the cave lakes water levels were clearly caused by a slush-ice barrier formation on the Berounka River above the town of Karlštejn, immediately below the studied river section. Ice jams form repeatedly at this site, since the floating slush ice accumulates here at the upper edge of already fully frozen, almost stagnant water above the Karlštejn weir. Thanks to the modest river gradient, the back flooding affects the river level up to several kilometers above the ice jam and consequently also affects the monitored cave lakes, but it did not reach the Beroun gauging station situated several $\mathrm{km}$ farther upstream. The existence of the temporary ice jams was later confirmed by ice accumulations high on the banks of the river channel. Unfortunately, no large flood with water filling the whole floodplain and flowing directly into the cave openings occurred during the period of automatic monitoring of the cave lake levels.

The hydraulic relationship between the river and the cave lakes levels is presented in Figure 6. Time intervals affected by ice jams were not used in the graphs and calculations. Both the river and the lake level were measured very precisely over time $( \pm 1 \mathrm{~cm})$, but there is considerable uncertainty in the relative positions of these two datasets $( \pm 0.3 \mathrm{~m})$. Therefore, in parts A-C of Figure 6 , the real position of the whole dataset may be shifted either to the left or to the right along the horizontal axis. In all the monitored caves, the temporal change in the cave level is clearly controlled by a difference between the level in the river and that in the cave. There is a linear relationship between these two parameters with coefficients of determination between 0.55 and 0.78 . The individual measuring points do not follow the regression line exactly. Instead, there is some tendency for hysteresis (most pronounced in the POD Cave). Temporal tracks of points in the upper left-hand part of the graphs, corresponding to the rising limbs of cave lake hydrographs, follow paths in a counterclockwise direction (see the arrows). The tracks can be interpreted by means of Figure 3, parts B and C, and Figure 6D. When the river level rises above the lake level $\left(H_{L}(\mathrm{t})-H_{R}(\mathrm{t})<0\right.$ and decreasing $), Q_{1}$ brings water towards the cave lake proportionally to the difference $H_{L}(\mathrm{t})-H_{R}(\mathrm{t}) . Q_{2}$ is positive and the water table in the cave rises. When $H_{L}(\mathrm{t})-H_{R}(\mathrm{t})$ is most negative, $Q_{2}$ abruptly falls to 0 or even to negative values (see Fig. 3A for the meaning of negative and positive $Q_{1}$ and $Q_{2}$ values). Then the absolute value of $\mathrm{Q}_{1}$ decreases proportionally to the decrease in the absolute value of $H_{L}(\mathrm{t})-H_{R}(\mathrm{t})$.

\section{Reaction of Cave Lakes to the Extreme Flood in August 2002}

The cave lakes were visited twice during this major flood event. The first visit took place on August 14 about 12 hours after the river peak, when the river level at the Beroun gauge was $710 \mathrm{~cm}$, following a peak of $796 \mathrm{~cm}$. The second visit was on August 16, when the river level had fallen to $400 \mathrm{~cm}$ on the Beroun gauge.

The main cause of the catastrophic August 2002 flood was intense precipitation, especially in the southern and southwestern parts of the Czech Republic, where the total precipitation in the period between August 6 and August 15 exceeded $300 \mathrm{~mm}$ in the mountain regions. Precipitation occurred in two separate periods, between August 6 and 7, and between August 11 and 13, when a larger amount fell. In the Bohemian Karst itself, the precipitation from August 6 to August 13 reached 130 to $160 \mathrm{~mm}$, approximately twice the normal total precipitation for August. As a consequence, the groundwater level rose quickly, and intense drip water from the unsaturated zone was encountered in some caves during the August 14 visit.

Figure 2 shows the response of the cave lakes to this major flood. Their behavior can be split into the following groups: A) The Berounka River directly flooded the entrance passages of the TET and MEN Caves. After the river peaked, the water level in the caves rapidly decreased to the level of the bottom of the cave entrance. Then the water level in both caves decreased very slowly due to the low permeability of the sedimentary fill between the cave lakes and the river and also because of the intense inflow of groundwater from the limestone aquifer into the caves. In the TET Cave, the water table fell slowly for a period of 1.5 years; B) In the TOM and DYN Caves, situated 120 to $140 \mathrm{~m}$ away from the river, no traces of direct river water intrusion were found. This is based on conductivity (Fig. 7) and temperature measurements. No muddy water was observed in the cave lakes. In the TOM cave, the water level rose $3.5 \mathrm{~m}$, as observed during the visit 12 hours after the peak of the flood. In the DYN cave, the water rose $3.6 \mathrm{~m}$, and the water level had dropped only $0.2 \mathrm{~m}$ below the maximum level recorded in this cave by the August 16 visit, 60 hours after the peak; C) The water of the POD Cave lake was composed of a mixture of river water with groundwater (temperature $14.2{ }^{\circ} \mathrm{C}$ and high turbidity, but 


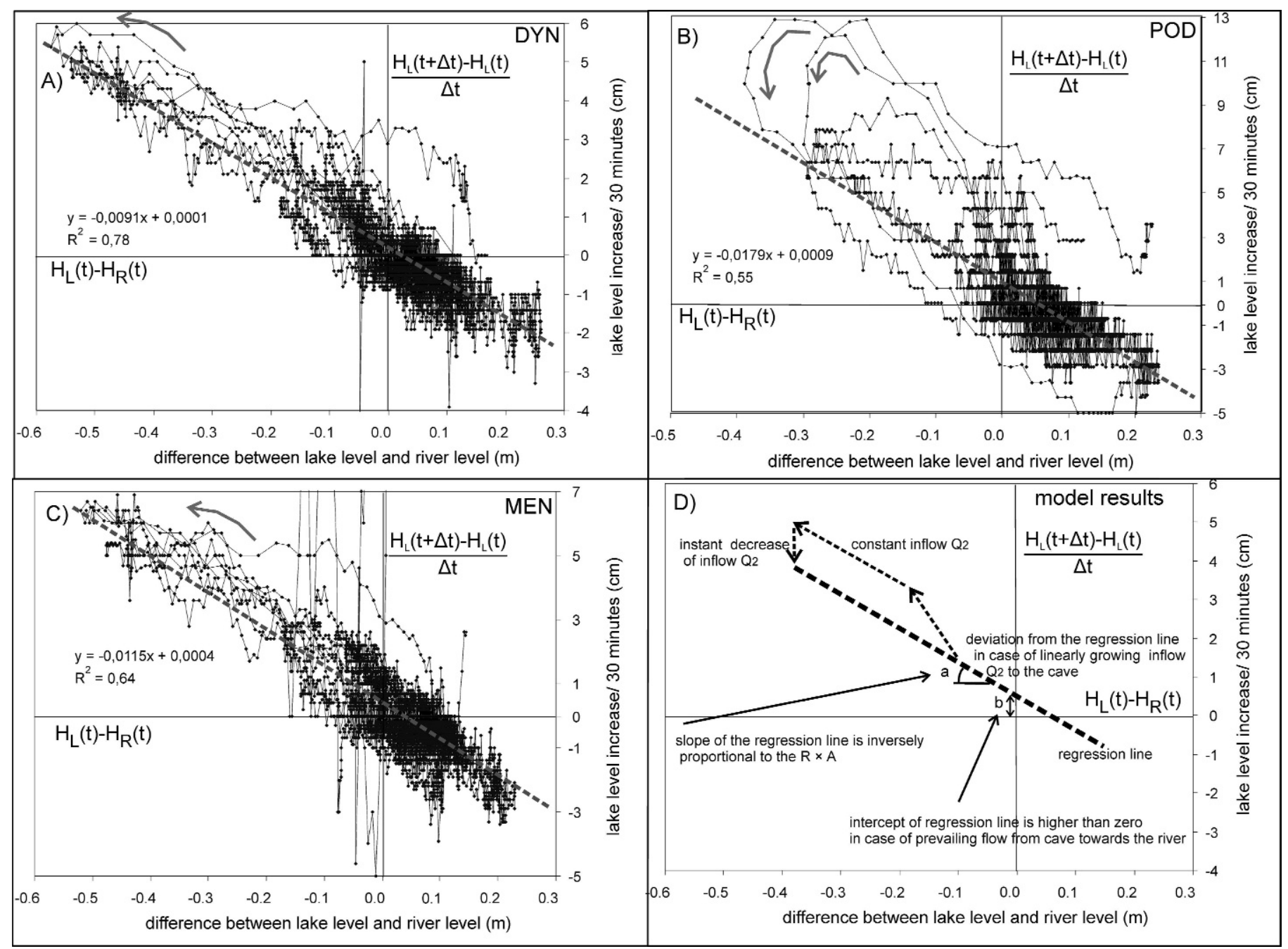

Figure 6. The relationship during the monitored period between the difference between the cave-lake and river level HL(t)$H R(t)$ and the change in lake level $\mathrm{HL}(\mathrm{t})-\mathrm{HL}(\mathrm{t}-1)$ between observations. Points are connected in time order. Bold arrows indicate trajectories during peaks of floods. Note that the positions of the data for a given cave in the horizontal direction may be consistently off by up to $0.3 \mathrm{~m}$. A. DYN cave. B. POD cave. C. MEN cave. D. Illustration of the relation of these plots to the model.

higher conductivity than river water; Fig. 7). Water in the cave reached the same level as in the river. The distance of the cave lake from the river was only $20 \mathrm{~m}$ at the peak of the flood.

\section{The Model of Hydraulic Head Propagation and Flow Between the River and Cave Lakes}

Equation (3) governs the hydraulic-head propagation between the river and the cave lakes. Solution of the inverse problems for the transmissivity of the alluvium between $10^{-3}$ and $10^{-2} \mathrm{~m}^{2} \mathrm{~s}^{-1}$ demonstrated that the storativity is $\leq 10^{-3}$ for the connecting path between the river and caves DYN, MEN, and POD. The low values of the storativity made it possible to further simplify the problem to Equations (4)-(6), which provide the model for the flow shown in Figure 3.
The relationship between the data in Figures $6 \mathrm{~A}-\mathrm{C}$ and this model is shown in Figure 6D. The slope indicated by angle $a$ is inversely proportional to the product $R \times A$. The POD Cave has the highest slope and thus the lowest $R \times A$ value, while DYN has the lowest slope and thus the highest $R \times A$ value. That the intercept of the regression line is slightly greater than zero for the POD and MEN caves indicates permanent inflow into the cave lake that is drained into the river $\left(Q_{2}\right)$.

The DYN Cave lake level oscillation during the 2002 flood was simulated using the slope -0.0091 of the linear regression between the difference in the DYN Cave lake and the river level and the change in the cave-lake level in $30 \mathrm{~min}$ time increments (Fig. 6A). The simulated level in the DYN Cave fits very well with the measured level in the cave (Fig. 8). This shows that flood water used the same path 
RESPONSE OF THE KARST PHREATIC ZONE TO FLOOD EVENTS IN A MAJOR RIVER (BOHEMIAN KARST, CZECH REPUBLIC) AND ITS IMPLiCATION FOR CAVE GENESIS

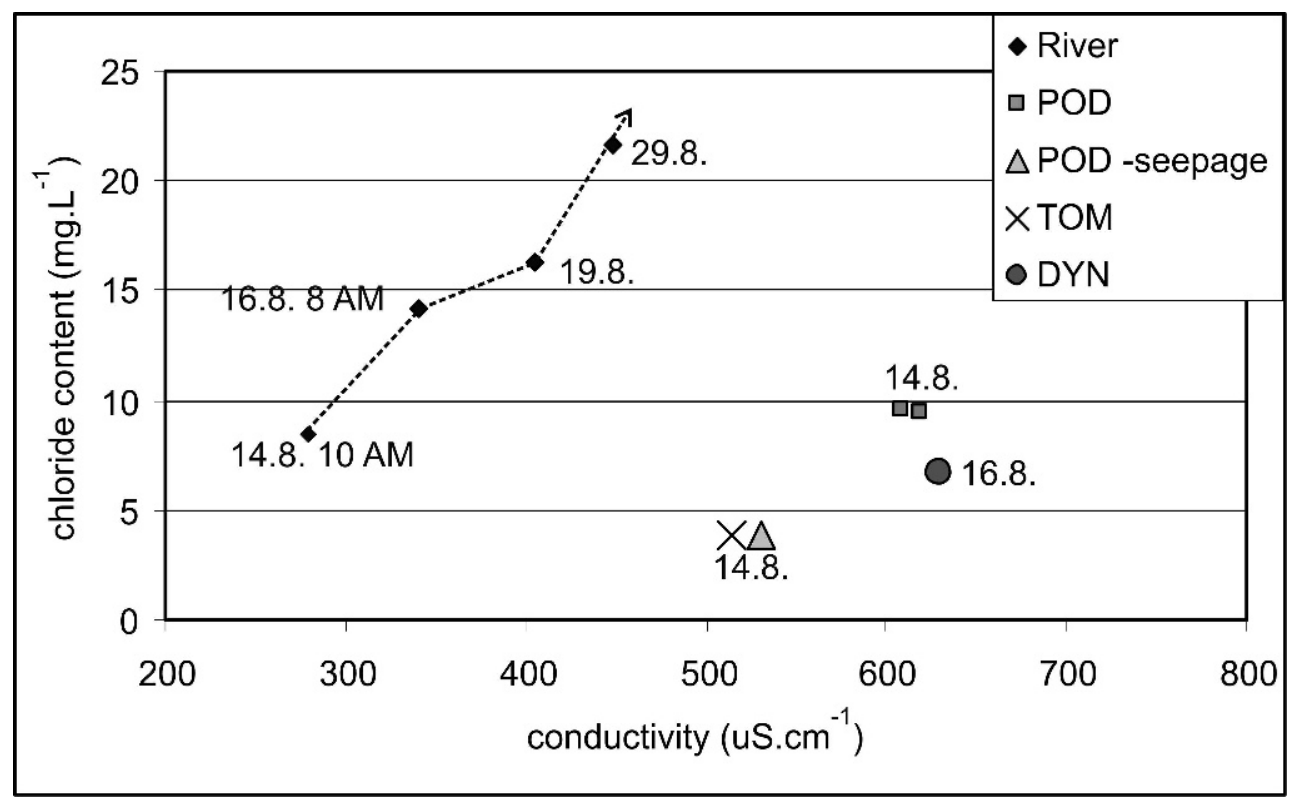

Figure 7. Conductivity and chloride contents in river water and selected cave lakes following the peak of the 2002 flood. Points are labeled by the day in August 2002.

between the river and the cave lake with the same parameters during the major flood in 2002 as during the much lower water stages when the level was logged. $\mathrm{R} \times \mathrm{A}$ thus remained constant even during this extreme flood. No additional conduit was activated during the flood in the DYN Cave.
The slope of the linear regression (Fig. 3 B, C, 6) can be potentially used for simulation of the lake level in other objects if tight correlation exists between $\left(H_{L}(\mathrm{t}+\Delta \mathrm{t})-H_{L}(\mathrm{t})\right) / \Delta t$ and $H_{L}(\mathrm{t})-H_{R}(\mathrm{t})$. The slope of the regression line can be used for simulation of the water table even when the relative position of the level in the river (or,

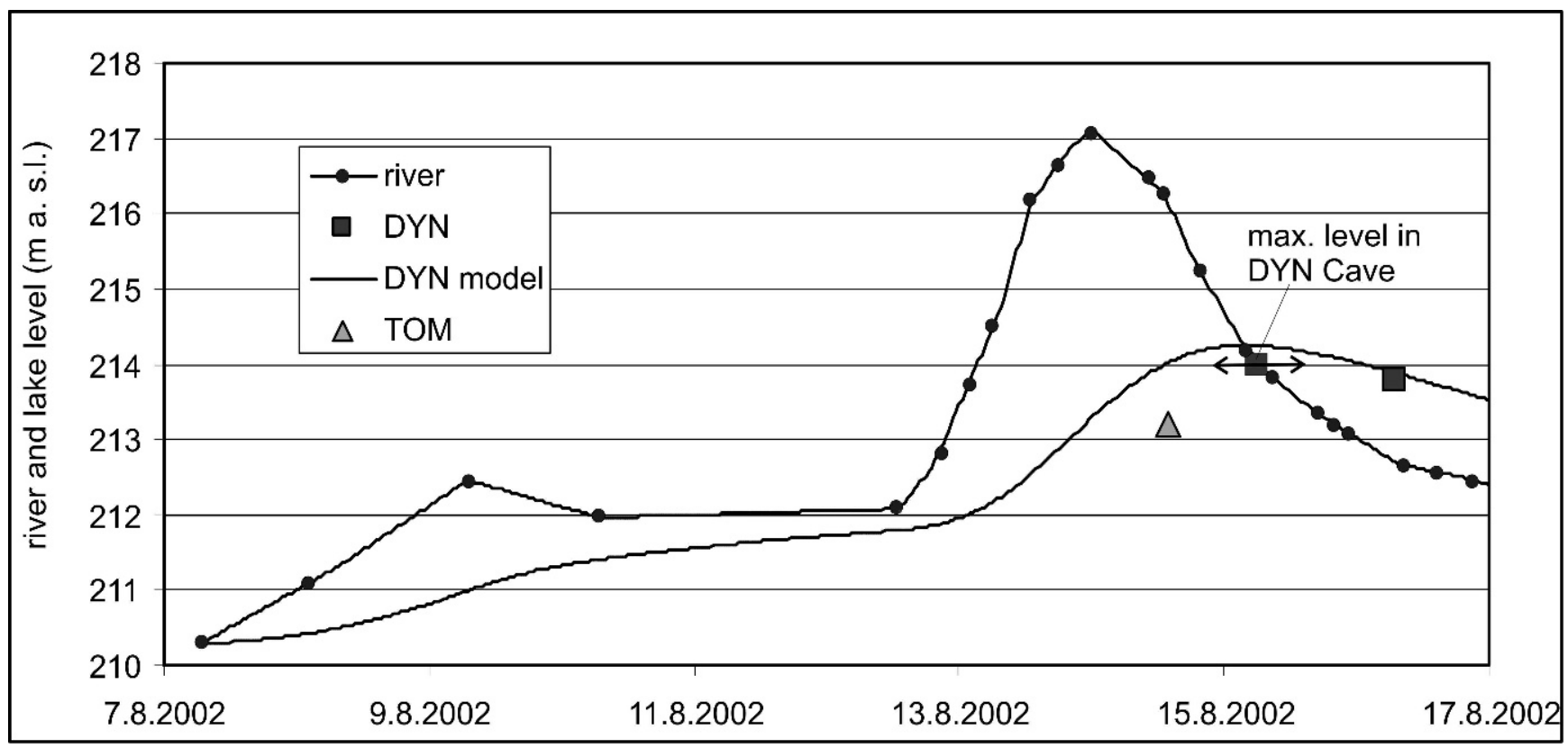

Figure 8. The flood on the Berounka River in August 2002, with some measured levels of the cave lakes. Note that the peak level of the lake in DYN is from traces left in the cave, and the timing of the peak is uncertain. The elevations of the cave lake observations relative to the river are uncertain by up to $0.3 \mathrm{~m}$. The model line is a simulation based on the model described in the text and the DYN cave parameters derived from Figure 6. The horizontal axis labels are day, month, and year. 


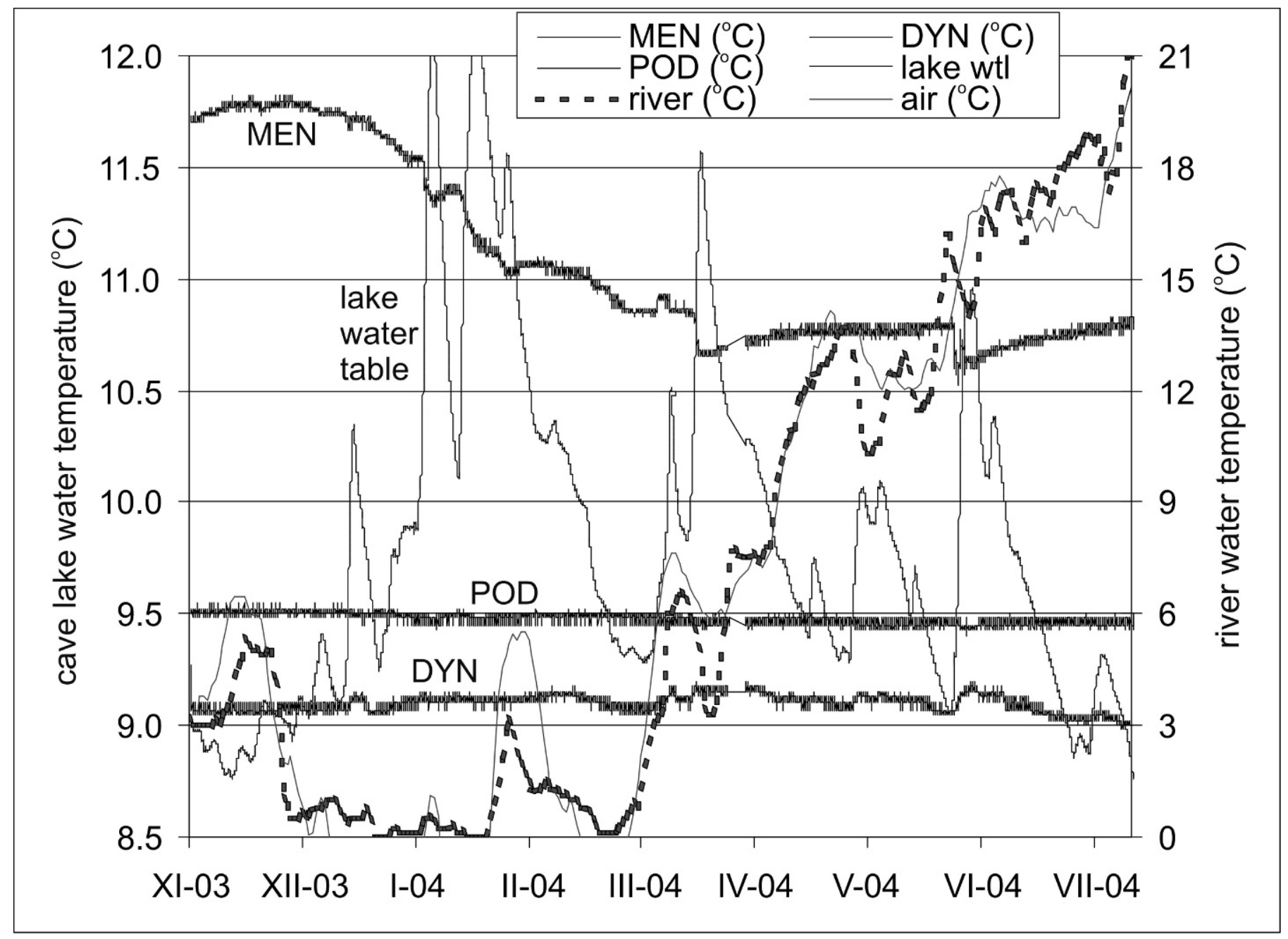

Figure 9. Measured temperatures of the cave lakes (left axis) and river and outdoor air (daily average; right axis). The water level in the POD cave lake from Figure 4 is superimposed (no scale). The horizontal scale is the month and year during the period of detailed data logging.

in general, any driving object in general) and the lake (or any dependent object such as a well) is not known exactly.

\section{Cave Lake Water Temperature}

The water temperature in the cave lakes (Fig. 9) is strongly affected by exposure of the terrain above the cave to radiation from the sun. While the TOM Cave, which is shielded from direct solar radiation by the subvertical north-facing side of the river canyon, has an annual average temperature of $8.4{ }^{\circ} \mathrm{C}$, the MEN Cave, situated under a south-facing slope just $400 \mathrm{~m}$ away, has an annual average temperature of $11.1^{\circ} \mathrm{C}$.

The lake temperature in the POD Cave is stable $(9.5 \pm$ $0.06{ }^{\circ} \mathrm{C}$ ), except for extreme flood events larger than those during the period of data collection. The DYN Cave exhibits a slight temperature oscillation over the range 9.0$9.3{ }^{\circ} \mathrm{C}$, and the water temperature is directly proportional to the lake water level ( $r$ of 0.62). This can be interpreted as a rise of water with slightly higher temperature from a deeper part of the cave lake towards the water table during a rising lake level. The TOM and NOV Cave lakes also exhibit only very limited temperature variations, based on manual measurements (less then $\pm 0.2{ }^{\circ} \mathrm{C}$ ).

In the MEN Cave, the water temperature ranged from 10.6 to $11.7{ }^{\circ} \mathrm{C}$. The temperature was highest in late November and lowest in June during the monitoring period, which is the opposite to the seasonal trend of the ground surface. Its temperature graph consists of a smooth sinusoidal annual oscillation with short-time deviations correlated with lake-level changes. The water temperature decreases during brief river rises even when the river water is warmer than the water of the cave lake. The MEN Cave lake's water-temperature oscillations are typical for combined heat transport (conduction together with convection), based on the study of Bundschuh (1997). Sinusoidal oscillation of the lake water temperature is generated by annual changes in the solar radiation that directly affect the soil temperature. This variation propagates with a delay, to 


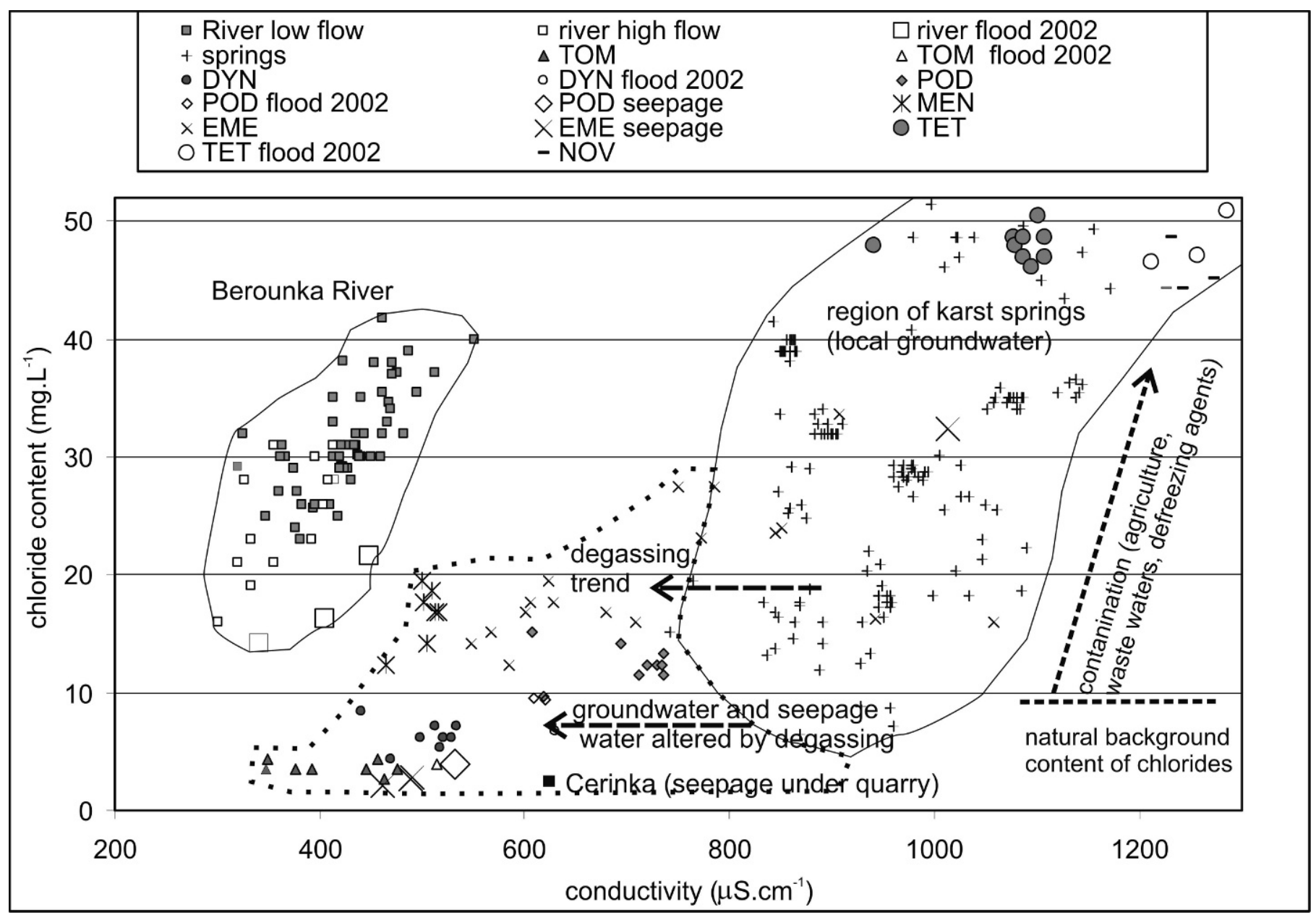

Figure 10. Plot of conductivity versus chloride content of water samples analyzed during the study. The area occupied by the river samples is clearly distinct from cave lakes, seepage, and other underground water. Degassing and calcite precipitation move underground waters horizontally to the left as shown, because chloride is conserved. The spring data (+) are from the Bohemian Karst, measured in 2000-2004. The chloride background indicated is the approximate minimum of those samples; near-surface underground water can be lower. The Cerinka quarry is $\mathbf{2} \mathbf{~ k m}$ north of the study area (Fig. 1).

depth by heat conduction via rocks. Short-lived peaks on the sinusoidal trend are a result of intrusion of water with lower temperature, most probably from the Quaternary gravels of the floodplain.

\section{Chemical Composition of the Cave Lake Water and ITS ORIGIN}

The water in the caves studied can be derived from two possible sources, the Berounka River and local groundwater. About 500 pairs of conductivity and chloride-content values were measured for springs, streams, and cave lakes and pools in the Bohemian Karst in the 2000-2004 period. The water of the Berounka River has low conductivity and thus low total dissolved solids (TDS), thanks to the location of most of its catchment on silicate rocks, above the studied karst area. The chloride content of the river water is elevated, thanks to multiple sources of pollution, both urban and agricultural. The conductivity-chloride plot of the water of the Berounka River differs from those of all the groundwater and cave lake water types of the Bohemian Karst (Fig. 10).

Springs and wells located both in the limestone and in the surrounding non-karstic rocks show considerably higher conductivity than the river water thanks to higher TDS. The chloride content varies from 6 to more than $50 \mathrm{mg} \mathrm{L} \mathrm{L}^{-1}$, depending on the degree of pollution in the catchment of a particular spring. The cave lake of the Čréínka Cave, situated under an open limestone quarry $3 \mathrm{~km}$ away from the river (Fig. 1), exhibits a chloride content as low as $2 \mathrm{mg} \mathrm{L}^{-1}$, thanks to the very low evapotranspiration enrichment of chloride ions in water infiltrating into limestone fractures with lack of soil cover removed by quarrying. Cave lakes and pools that retain water from the unsaturated zone could be split into two groups, based on their observed chemistry.

Some of the lakes and pools fall inside the field typical for the karst springs (Fig. 10) and their chemical composition is 


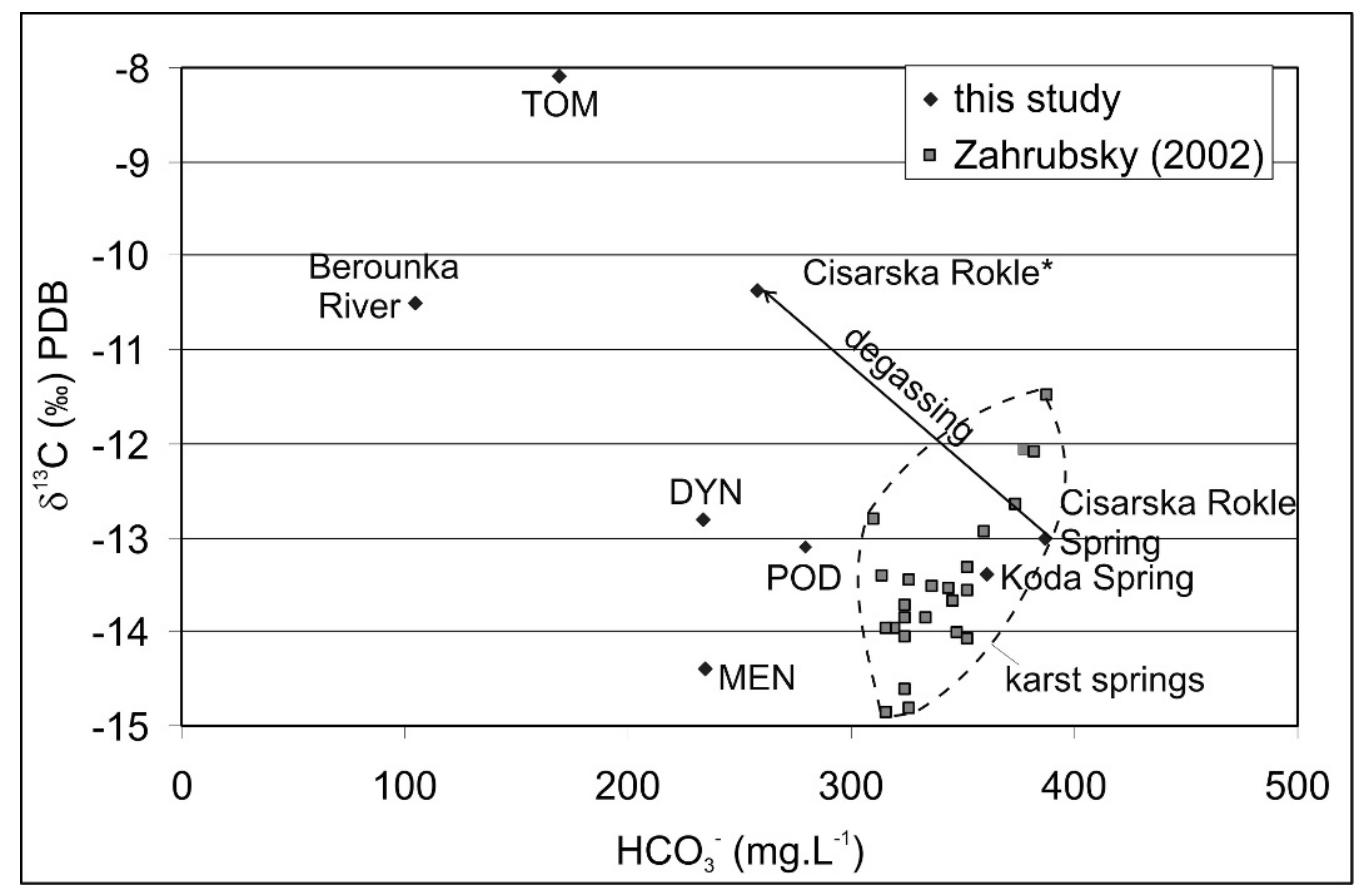

Figure 11. Bicarbonate and $\delta^{13} \mathrm{C}$ values for some samples analyzed in this study. Bohemian karst springs fall in the area outlined. As an example of the effect of degassing, values for the Cisarska Rokle Spring (Fig. 1) are shown at the spring and after $1 \mathrm{~km}$ of flow on the surface toward the river $\left(^{*}\right)$.

also the same (NOV Cave, TET Cave, part of EME Cave. These lakes are recharged by local groundwater with no subsequent changes in the water chemistry.

Some lakes and pools exhibit low conductivity and low chloride content (the TOM, DYN and POD Caves and some of the EME Cave pools). On the conductivity-chloride plot, they fall neither in the field of karst springs nor in the area of Berounka River water (Fig. 10). As chloride is a conservative tracer, these waters cannot be derived from river water, which has a much higher chloride content. The calcium and alkalinity contents in some of these waters are up to two or three times lower than those of the karst springs. Other components have similar concentrations to those measured in the karst springs. These compositions can be explained by prolonged equilibration of the water with a cave atmosphere containing low $\mathrm{CO}_{2}$ partial pressure $(0.04$ to 0.18 vol. $\% \mathrm{CO}_{2}$ in the studied caves).

Long-term stagnation of water in lakes and pools and high water $\mathrm{pH}$ are in agreement with this explanation, as are their high $\delta^{13} \mathrm{C}$ values (Fig. 11). The TOM Cave lake shows the most significant loss of calcium and bicarbonate ions by $\mathrm{CO}_{2}$ degassing and calcite precipitation. It contains only $66-70 \mathrm{mg} \mathrm{L}^{-1}$ calcium compared to $140-200 \mathrm{mg} \mathrm{L}^{-1}$ typical for the karst springs of the area. In the TOM and POD Caves, the content of both components varies slightly over time, probably due to variations in the intensity of flow through the cave lake and mixing of stagnant lake water with water from the unsaturated or saturated zones. Generally, the lowest TDS and highest $\mathrm{pH}$ values were detected during the winter of 2003-2004, after a more than year-long recession in groundwater levels. The very low chloride content in the TOM Cave shows that the cave lake is predominantly supplied from direct infiltration in the quarry above the cave.

We studied the temporal behavior of chloride to discover whether the cave lakes are partly recharged by river water (Fig 12). The figure clearly demonstrates that the temporal trends in river water and cave lakes are different. During the recession (March 2003 to October 2003), the chloride content generally rose in the river water, whereas it was quite stable in the cave lakes. It decreased slowly in the MEN Cave lake, probably as a consequence of dilution of the river water injected during the 2002 flood by local groundwater. Inflow of river water was thus not observed in any of the studied caves during low and normal water stages.

The cave lakes were slightly oversaturated with respect to calcite (SI 0.2 to 0.7 ). River water was undersaturated with respect to calcite during high water stages (SI -0.5$)$ but oversaturated during low and normal water stages (SI 1.0 to 1.3$)$

Interaction Between the River and the Limestone Aquifer: A Model

Based on observations of the water level in wells and caves located farther away from the river, the minimum hydraulic gradient in the limestone aquifer is between 1 and $2 \%$, and locally higher. The river slope is significantly less $(0.064 \%$, on an average, see Figure 2). Therefore the groundwater tends to 


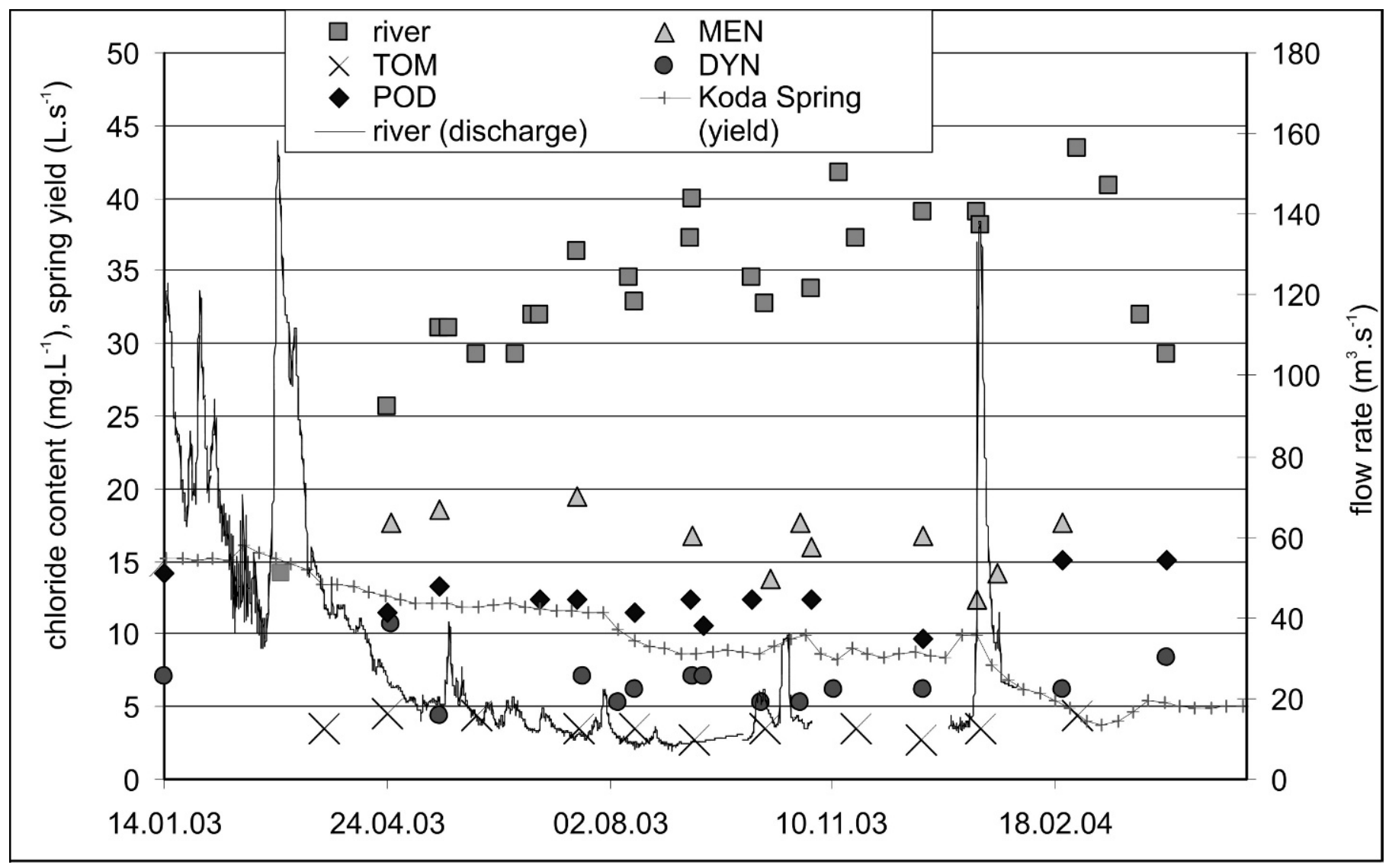

Figure 12. Chloride content in the river and monitored cave lakes. The discharge (not level) of the river at the Beroun gauge is shown for comparison, as is the yield of the Koda Spring (Fig. 1). The time scale is day.month.year after 2000. Note that the period covered is different from that of Figure 4.

discharge into the river at steady state. River water enters the limestone aquifer only temporarily, during flood events or during winter ice jams, when the high water level in the river canyon injects river water into the limestone aquifer. During major floods, the water level in the limestone aquifer is several meters below the water level in the river, thus enabling very effective injection of floodwaters into the karst porosity up to a distance of a few hundred meters away from the river (e.g., the EME Cave). After floods, water returns back to the river by the same path.

Observations of cave lakes during the August 2002 flood clearly demonstrated the importance of open cave entrances for flooding by river water. Caves with open entrances at elevations accessible to flood intrusion were extensively flooded by river water. Caves separated from the river by a Quaternary alluvium were flooded by elevated groundwater instead of river water. The water level in such caves rose to only about half of the river's peak level. River water penetrated only a few tens of meters into the limestone aquifer in these cases.

Under current conditions, massive flood-flow injection only occurs in caves, such as MEM, EME, and TET, with exposed openings below the level of river floods, which, as in 2002 , can be up to $7 \mathrm{~m}$ above the normal river stage. In caves separated from the river by Quaternary alluvium, flood-flow injection is strongly reduced or absent at the present time. In those caves, flood-flow injection was a very important process during some periods within the last two glacial periods, when the rocky faces of the river canyon were not covered by finegrained sediments and river water was easily injected into fractures and cave openings. At present, the flood-flow injection is also reduced by anthropogenic factors, especially the 1 to $2 \mathrm{~m}$ thick late Holocene fine-grained fluvial sediments covering the floodplain surface, largely the result of enhanced erosion due to deforestation and extension of agriculture in the river catchment since the thirteenth century.

The shape of vertical section of the caves is also an important factor for the extent of river-water penetration into the limestone aquifer during a flood (Fig. 13). In highly permeable shallow cave passages, where part of the passages is situated in the epiphreatic (periodically flooded) zone, the river water can penetrate several hundred meters into the limestone aquifer, as there is enough room for incoming river water. (EME Cave is an example.) In high volume phreatic loops connected to only small spaces in the epiphreatic zone, the rising water fills less volume. Consequently, river water cannot penetrate farther into the limestone aquifer (TOM and POD caves). 


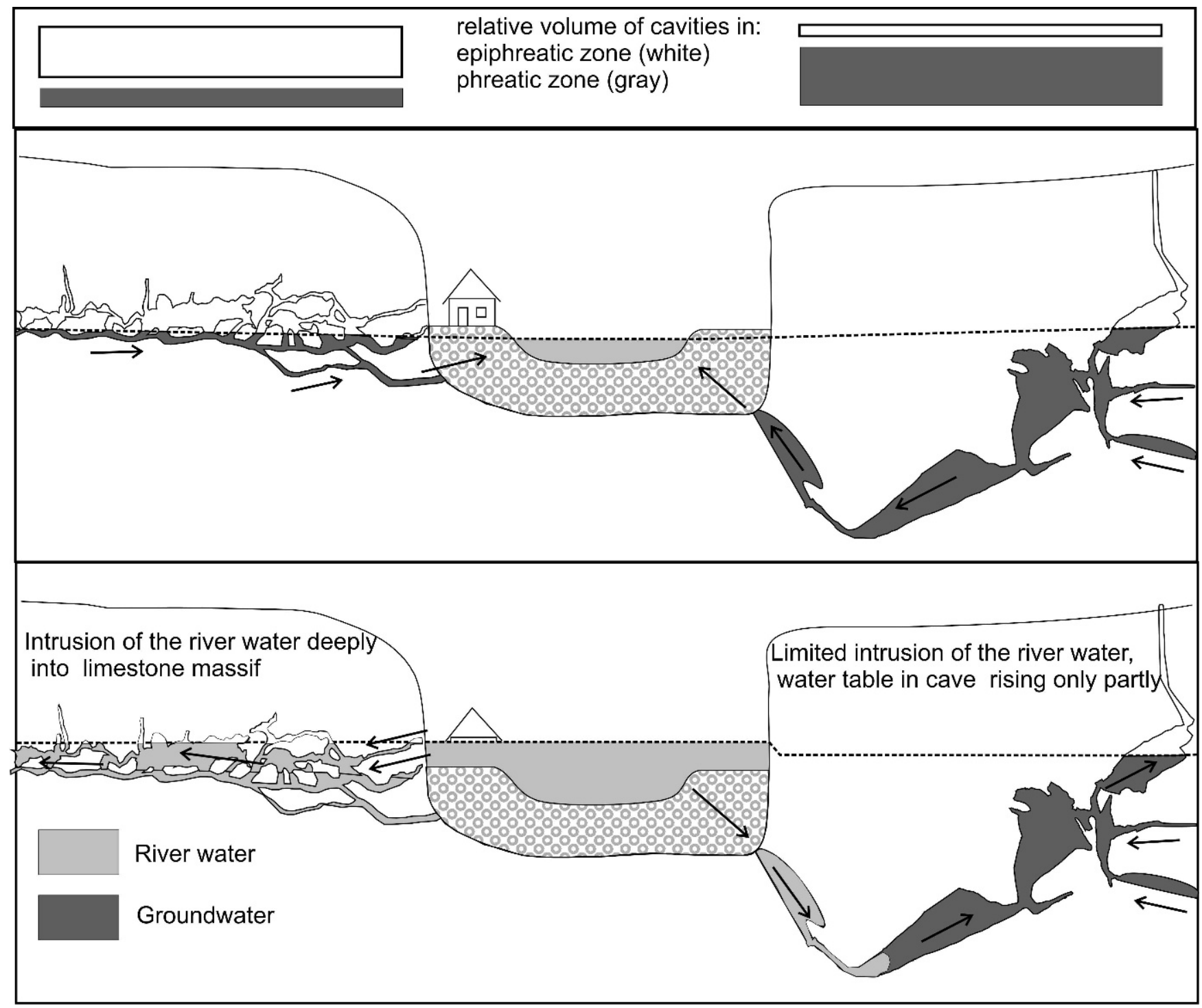

Figure 13. Conceptual models of flow between the river and limestone aquifer during, top, normal river stage and, bottom, a high flood that reaches entrances above the alluvium. The cave on the left is predominantly epiphreatic and has entrances directly accessible to floods; the cave on the right is predominantly phreatic and connects to the river only through alluvium.

One new result of this study was the observation of water level increases in the river (and in the cave lakes) related to ice jams blocking the river and thus elevating the river level during the winter. These ice jams are of two types, formed by either the accumulation of moving slush ice during the periods with the lowest temperatures or spring ice during the spring thaw. Historically, ice jams have been recorded on the Berounka River (e.g., in 1940, 1942 and 1947; Matoušek, 2004) that locally increased the water level by more than $5 \mathrm{~m}$. During the summer floods, the river-water density is usually lower than that of the cave-lake water, and the river floodwaters mostly penetrate into the cave in the upper part of the water column of the flooded section. The water of winter floods can be more dense than the water of cave lakes and thus penetrates preferentially into their deepest parts.
The behavior of floodwaters derived from summer floods and winter floods related to ice jams might therefore be different in the flooded cave sections.

During the glacial periods, increases in the water level in the river caused by ice jams could have been much more frequent than in the contemporary climate. The difference in the water level above the ice jam and below it can be several meters. This can induce strong injections of river waters into the karst and even the formation of karst flow paths in the limestone massif parallel to the river.

\section{Conclusions}

Based on the results presented in this study, the following conclusions can be reached regarding the relationships

Journal of Cave and Karst Studies, April 2012 • 79 
between the cave lakes and the adjacent medium-gradient Berounka River:

During minor water level peaks in the river of up to $1.5 \mathrm{~m}$ above normal, a water level oscillation in the karst aquifer is induced. The oscillation amplitude is slightly dampened and delayed compared to that in the river. Based on the groundwater chemistry, it can be concluded that the river water did not flow more than a few tens of meters into the karst aquifer behind the rocky slopes of the river canyon and did not reach the sampled cave lakes. Low bicarbonate contents and high $\delta^{13} \mathrm{C}$ values indicate that some of the cave lakes' waters are stagnant and undergo $\mathrm{CO}_{2}$ degassing accompanied by calcite precipitation.

During major river floods (recurrence interval $>100$ years), the river water rapidly floods the caves through openings in the sides of the river canyon, while those connected to the river only via the alluvium are flooded by the elevated groundwater level, and the increase in the water level in them is only about $50 \%$ of the increase in the river level. A simple hydraulic model was successfully used to simulate and explain the water table oscillations in the cave lakes.

Thanks to the very low gradient of the river, the river water cannot infiltrate into the limestone aquifer and flow there parallel to the course of the river. Instead, river water is injected into the aquifer only during flood events before and during the peak. Then the water drains back into the river. This process is substantially impeded by lowpermeability late Holocene fine-grained fluvial sediments that cap the coarse gravels in the river floodplain.

Increases in the level of the river by ice jams were recognized as one factor that can be important in speleogenesis. Under these events, temporary flow of river water through the karst aquifer parallel to the river is possible because of the very high relief across the ice dam.

Fast speleogenesis by means of flood injection could be expected in periods when the river canyon was bare or filled by gravel alone. Such conditions characterized the last two glacial periods and transition to the Holocene in the studied river valley.

\section{ACKNOWLEDGMENTS}

The research was financed by research projects MSM00216220855 and GAUR80509 (Charles University in Prague and Institutional Research Plan). The participation of Karel Žák was supported by research program No. AV0Z30130516, by project GA CR P210/10/1760, and by project $\mathrm{SP} / 2 \mathrm{e} 1 / 153$.

\section{REFERENCES}

Anderson, R.S., and Anderson, S.P., 2010, Geomorphology: The Mechanics and Chemistry of Landscapes Cambridge University Press, 640 p.

Bailly-Comte, V., Jourde, H., and Pistre, S., 2009, Conceptualization and classification of groundwater-surface water hydrodynamic interactions in karst watersheds: case of karst watershed of the Coulazou river (Southern France): Journal of Hydrology, v. 376, p. 456-462. doi: 10.1016/j.jhydrol.2009.07.053.

Bailly-Comte, V., Martin, J.B., Jourde, H., Screaton, E.J., Pistre, S., and Langston, A., 2010, Water exchange and pressure transfer between conduits and matrix and their influence on hydrodynamics of two karst aquifers with sinking streams: Journal of Hydrology, v. 386, p. 55-56. doi: 10.1016/j.jhydrol.2010.03.005.

Bosák, P., 1998, The evolution of karst and caves in the Koněprusy region (Bohemian Karst, Czech Republic), Part II: Hydrotermal paleokarst: Acta Carsologica, v. 27, no. 2, p. 41-61.

Bosák, P., Cílek, V., and Bednáŕová, J., 1993, Tertiary morfogeny and karstogenesis of the Bohemian karst, Prague, The Czech Speleological Society, v. 21 (Karst sediments), p. 10-19.

Bruthans, J., and Zeman, O., 2000, New findings on hydrogeology of the Bohemian Karst: Český kras, v. 26, p. 41-49. (in Czech with English abstract).

Bruthans, J., and Zeman, O., 2001, New data on character and evolution of underground karst forms in the Bohemian Karst and other areas with diffuse recharge mode in the Czech Republic: Český Kras, v. 27, p. 21-29. (in Czech with English abstract).

Bruthans, J., and Zeman, O., 2003, Factors controlling exokarst morphology and sediment transport through caves: Comparison of carbonate and salt karst: Acta Carsologica, v. 32, no. 1, p. 83-99.

Bundschuh, J., 1997, Temporal variations of spring water temperatures in relation to the extents of heat transport modes occurring in the karstified lower Gypsum-Keuper aquifer (Karnian, southern Germany), in Proceedings of the 12th International Congress of Speleology, Conference on Limestone Hydrology and Fissured Media, 6th, Switzerland, Volume 2, p. 129-132.

Chlupáč, I., Brzobohaty, R., Kovanda, J., and Stráník, L., 2002, Geologická minulost Ceské republiky, Prague, Academia, 436 p.

Choquette, P.W., and Pray, L.C., 1970, Geologic nomenclature and classification of porosity in sedimentary carbonates: American Association of Petroleum Geologists Bulletin, v. 5, no. 2, p. 207-250.

Cílek, V., Dobeš, P., and Žák, K., 1994, Formation conditions of calcite veins in the quarry "V Kozle (Hostim I, Alkazar)" in the Bohemian Karst: Journal of the Czech Geological Society, v. 39, no. 4, p. $313-318$.

Doctor, D.H., Calvin, A.E., Petrič, M., Kogovšek, J., Urbanc, J., Lojen, S., and Stichler, W., 2006, Quantification of karst aquifer discharge components during storm events through end-member mixing analysis using natural chemistry and stable isotopes as tracers: Hydrogeology Journal, v. 14, p. 1171-1191.

Elleder, L., 2004, Floods in city of Beroun: Český kras, v. 30, p. 59-62. (in Czech with English abstract).

Florea, L.J., and Vacher, H.L., 2006, Springflow hydrographs: eogenetic vs. telogenetic karst: Ground Water, v. 44, no. 3, p. 352-361.

Havlíček, V., 1989, Geological map, Prague, Czech Geological Survey, scale 1:250,000, sheet Králův Dvůr, 12-413, 1 sheet.

Horáček, I., and Ložek, V., 1988, Palaeozoology and the Mid-European Quaternary past: scope of the approach and selected results: Rozpravy Ceskoslovenské akademie věd, řada matematických a prírodních věd, v. 98 , no. 4 , p. $1-102$.

Katz, B.G., Catches, J.S., Bullen, T.D., and Michel, R.L., 1998, Changes in the isotopic and chemical composition of ground water resulting from recharge pulse from sinking stream: Journal of Hydrology, v. 211 , p. $178-207$.

Klimchouk, A.B., Ford, D.C., Palmer, A.N., and Dreybrodt, W., 2000, Speleogenesis, Evolution of Karst Aquifers, Huntsville, Alabama, National Speleological Society, $521 \mathrm{p}$.

Kočí, A., 1991, Palaeomagnetic investigation of the Beroun highway section: Antropozoikum, Ústřední ústav geologický, v. 20, p. 103-109.

Kovanda, J., 1991, The significance of the Lower Pleistocene sedimentary complex of the Beroun highway: Antropozoikum, Ústřední ústav geologický, v. 20, p. 129-142.

Kovanda, J., and Herzogová, J., 1986, Druhé chronologické paradoxon v Kruhovém lomu u Srbska: Český kras, v. 12, p. 59-62.

Kukla, J., and Ložek, V., 1993, Průzkum říčních teras v okolí Tetína a otázka prvního říčního paradoxon: The Czech Speleological Society, v. 21 (Karst sediments), p. 30-40.

Martin, J.B., and Dean, R.W., 2001, Exchange of water between conduit and matrix in the Floridan Aquifer: Chemical Geology, v. 179, p. 145-165. doi: 10.1016/S0009-2541(01)00320-5. 
Matoušek, V., 2004, Ledový režim vodních toků: Praha, Výzkumný ústav vodohospodářský T.G.Masaryka, Práce a Studie, v. 199, p. 1-203.

MoE CR (Ministry of the Environment of the Czech Republic), 2003, Final report of the project Evaluation of catastrophic flood of August 2002 and of proposal of the Flood preventive system, Praha, MZ̃P CR, unpublished report, the final version accepted by the Government of the Czech Republic on January 21, 2004. (In Czech).

Opsahl, S.P., Chapal, S.E., Hicks, D.W., and Wheeler, C.K., 2007, Evaluation of ground-water and surface-water exchanges using streamflow difference analyses: Journal of the American Water Resources Association, v. 43, no. 5, p. 1132-1141. doi: 10.1111/j.1752-1688.2007. 00093.x.

Palmer, A.N., 1991, Origin and morphology of limestone caves: Geological Society of America Bulletin, v. 103, p. 1-21. doi: 10.1130/0016-7606(1991)103<0001:OAMOLC $>2.3 . C O ; 2$.

Parkhurst, D.L., and Appelo, C.A.J., 1999, User's guide to PHREEQC (Version 2) - A computer program for speciation, batch-reaction, onedimensional transport, and inverse geochemical calculations, U.S. Geology Survey Water Resources Investigations Report 99-4259, $312 \mathrm{p}$.

Springer, G.S., Rowe, H.D., Hardt, B., Cocina, F.G., Edwards, R.L., and Cheng, H., 2009, Climate driven changes in river channel morphology and base level during the Holocene and Late Pleistocene of southeastern West Virginia: Journal of Cave and Karst Studies, v. 71 , no. 2, p. 121-129.
Vacher, H.L., and Mylroie, J.L., 2002, Eogenetic karst from the perspective of an equivalent porous medium: Carbonates and Evaporites, v. 17, no. 2, p. 182-196. doi: 10.1007/BF03176484.

Včíslová, B., 1980, Silur - devon Barrandienu - II. fáze - závěrečná zpráva, Praha, Stavební geologie, $191 \mathrm{p}$.

Záhrubský, K., 2003, Možnosti využití izotopů uhlíku ${ }^{14} \mathrm{C}$ a ${ }^{13} \mathrm{C}$ v hydrogeologii Českého krasu [Ph.D. thesis]: Praha, Charles University in Prague, $136 \mathrm{p}$.

Žák, K., Cílek, V., Danielisová, A., Hlaváč, J., Kadlec, J., Kyncl, T., Pokorný, P., and Světlík, I., 2010, Holocene section in the excavation for construction of the Hýskov Hydropower Plant and its bearing to the understanding of the Berounka River floodplain evolution: Český kras, v. 36, p. 42-51. (in Czech with English abstract).

Žák, K., and Elleder, L., 2007, History of floods in the karst canyon of the Berounka River in surroundings of Srbsko village during the last two hundred years: Český kras, v. 33, p. 9-15. (in Czech with English abstract).

Žák, K., Hladíková, J., Buzek, F., Kadlecová, R., Ložek, V., Cílek, V., Kadlec, J., Žigová, A., Bruthans, J., and Štastný, M., 2001a, Karstic spring and calcareous tufa accumulation of Holocene age in Svatý Jan pod Skalou (Bohemian Karst), Praha, Czech Geological Survey, Special Papers 13, no. 1, 135 p. (in Czech with extended English summary).

Žák, K., Táborský, Z., Lachmanová, M., and Pudilová, M., 2001b, Heavy mineral assemblages in allochthonous clastic cave sediments of the Bohemian Karst: A pilot study: Český kras, v. 27, p. 5-14. (in Czech with English abstract). 